\title{
RANCANG BANGUN PROTOTYPE BERBASIS WEB SEBAGAI IMPLEMENTASI PRAKTIK WIRAUSAHA MAHASISWA DI KOTA SEMARANG
}

\author{
Mariana Kristiyanti \\ Program Studi KPN, STIMART-AMNI Semarang \\ mkristiyanti@yahoo.com
}

\begin{abstract}
In Semarang, college growth offers the entrepreneurial traits for educative competitor of expanding very fast. Mostly, college has used the information system to market result of practice entrepreneurial all its student, but on the way, growth practice the entrepreneurial among student impress tardy and product and also service which they yield, not yet optimal of its information spreading. Designedly develop build the in wrought prototype system accomodating all result practice the wirausaha competitor educated by which is gone the round of in various college in Semarang, expected can give the information widely hit result of practice entrepreneurial in web. And indirectly, the web can become the individuality of Semarang providing information of result of child masterpiece nation passing the Website. Design to develop, build the prototype base on the Web to find the product yielded by all students in Semarang, representing picture of Information System to be made later. Research method used by Observation to College offering program of entrepreneurial and interview, while designing to develop build the Prototype of result of this practice entrepreneurial use the Flowchat System.
\end{abstract}

Keywords: prototype, develop build, WEB, entrepreneurial practice

\section{PENDAHULUAN}

Untuk mendukung terciptanya pengusaha-pengusaha baru yang kompeten di bidangnya, Perguruan Tinggi baik negeri maupun swasta, berlomba-lomba untuk mendidik mahasiswanya menjadi pengusaha yang berhasil. Berbagai matakuliah yang ada di fakultas, diberi muatan materi dunia usaha dan bisnis agar mahasiswa menjadi lulusan yang mandiri yang dapat menciptakan lapangan usaha dan dapat memajukan perekonomian di daerahnya masing-masing. Hal ini terbukti dengan penelitian terdahulu yang dilakukan oleh Warsitaningsih (2003) yang meneliti mengenai pentingnya menumbuhkan jiwa wirausaha pada para mahasiswa jurusan tata boga karena didapati para mahasiswa pada Program Studi Spesialisasi Pendidikan Tata Boga telah merasakan manfaat pembelajaran bidang boga yang telah diterimanya karena lebih dari setengahnya telah berani merintis usaha home industry dan kurang dari setengahnya, walaupun berminat merintis usaha home 
industry, namun merasa belum berani untuk mencoba dan kurang percaya diri. Oleh karena itu, guna menambahkan jiwa wirausaha, perlu ditambahkan mata kuliah kewirausahaan.

Bagi Perguruan Tinggi, tidak hanya lulusan yang lebih berkualitas akan didapatkan, tetapi penerapan ilmu dan pengetahuan yang dihasilkan akan menjadi sangat nyata. Bahkan secara ekonomis Perguruan Tinggi dan dosennya dapat memperoleh manfaat tambahan dari proses komersialisasi Iptek yang dilakukan oleh lulusannya. Integrasi dunia usaha dan dunia akademis akan tercipta dengan erat melalui proses ini. Penciptaan wirausaha yang lebih berkualitas, bukan wirausaha jalanan yang muncul karena keterpaksaan akibat lapangan kerja yang terbatas, akan memberikan dampak ekonomi yang luar biasa bagi bangsa ini. Menjadikan mahasiswa sebagai technopreneur dapat dimulai selama masa perkuliahan, sehingga setelah lulus mahasiswa sudah mempunyai usaha sendiri yang siap untuk dijalankan dan dikembangkan.

Hasil penelitian dari Penny et al. (2010), menyatakan bahwa salah satu penyebab rendahnya aktivitas kewirausahaan adalah lulusan Perguruan Tinggi yang pada kenyataannya mempunyai kemampuan dan keilmuan yang lebih tinggi, masih banyak yang berperan sebagai pencari kerja dari pada sebagai pencipta lapangan kerja. Hal ini mungkin disebabkan oleh karena sistem pembelajaran yang diterapkan di berbagai Perguruan Tinggi di Indonesia lebih terfokus pada bagaimana menyiapkan para mahasiswa yang cepat lulus dan mendapat pekerjaan dari pada menciptakan lulusan yang siap menciptakan lapangan kerja. Rendahnya aktivitas kewirausahaan ini dapat menyebabkan tingginya angka pengangguran karena tidak ada ekspansi kegiatan usaha. Salah satu cara untuk menumbuhkan jiwa berwirausaha di kalangan mahasiswa adalah dengan mengembangkan kewirausahaan yang berbasis teknologi (technopreneurship). Untuk merancang kurikulum dan pengajaran materi, inovasi teknologi yang dapat memberikan dampak sosial dan ekonomi, yang menjadikan teknologi sebagai solusi bagi permasalahan yang dihadapi oleh masyarakat miskin. Kegiatan ini merupakan wadah untuk meningkatkan kesadaran mahasiswa dalam menciptakan teknologi baru serta pengembangan bisnis berbasis inovasi. Kegiatan ini telah membuka wawasan bagi mahasiswa yang berasal dari ilmu sosial bahwa pemanfaatan teknologi sebagai dasar berwirausaha dapat dilakukan siapa saja.

Dalam riset pendahuluan, melalui laman www.kopertis6.or.id, di wilayah Kopertis VI tercatat ada 33 Universitas, dua Institut, 71 Sekolah Tinggi, 18 Politeknik dan 100 Akademi, sehingga jika ditotal ada 22 Perguruan Tinggi di bawah naungan Kopertis Wilayah VI, namun tidak sampai setengahnya memiliki laman yang aktif dan up to date. Hal ini merupakan penyebab program usaha untuk para mahasiswa tertinggal dalam mengadopsi teknologi informasi di dalam usahanya. Sistem informasi yang digunakan oleh Perguruan Tinggi belum terlalu optimal untuk memasarkan produk atau jasa yang dihasilkan oleh para mahasiswanya, sementara 
saat ini zaman sudah semakin canggih disertai dengan keberadaan teknologi yang modern. Maka tentu sangat minim peluang untuk mampu bersaing di dunia usaha jika sistem yang ada di Perguruan Tinggi tidak melakukan perkembangan dengan bekerjasama dengan pihak lain guna memasarkan produk atau jasa karya mahasiswanya. Oleh karena itu, dengan meningkatkan kemampuan mahasiswa di bidang teknologi, diharapkan dapat menyelesaikan beberapa permasalahan yang dihadapi dalam dunia usaha.

Menyikapi hal di atas, salah satu penyelesaiannya adalah dengan membuatkan prototype sistem terpadu yang menampung hasil usaha peserta didik yang tersebar di berbagai Perguruan Tinggi di Semarang, untuk disatukan dalam sebuah situs web (World Electronic Browser), dimana prototype yang dibangun merupakan cikal bakal pembuatan web yang berisi produk-produk dan jasa yang dihasilkan oleh mahasiswa yang berdomisili di Kota Semarang. Web tersebut dapat menjadi ciri khas Kota Semarang yang menyediakan hasil karya anak bangsa melalui media website.

Era globalisasi dan kemajuan teknologi informasi yang berkembang sangat cepat telah memaksa kita mempersiapkan diri mau tidak mau untuk masuk dan menjadi bagian aktif dari masyarakat ekonomi-informasi. Internet economy mendorong globalisasi dan networking dunia usaha. Kondisi di atas menjadikan pasar dan perdagangan makin terbuka tanpa batas, serta peluang yang setara bagi pelaku-pelaku bisnis tidak mengenal apakah berasal dari mahasiswa, pengusaha besar, menengah, atau pun kecil (Frinces 2004).

Di Jawa Tengah, khususnya di Kota Semarang, perkembangan Perguruan Tinggi yang menawarkan program dunia usaha bagi peserta didiknya sangat pesat. Sebagian Perguruan Tinggi sudah menggunakan sistem informasi untuk memasarkan usaha para mahasiswanya, tetapi kesemuanya belum terpublikasi dengan baik. Dengan dibuatnya sebuah prototype sistem informasi berbasis web untuk mengenalkan produk-produk yang dihasilkan oleh para mahasiswa di Kota Semarang, diharapkan Perguruan Tinggi juga dapat mengakses informasi tidak hanya untuk peserta didiknya saja, tetapi juga peserta didik dari Perguruan Tinggi lainnya. Hal ini juga bisa menjadikan tantangan tersendiri bagi mahasiswa maupun Perguruan Tingginya, untuk terus berinovasi sehingga dapat bersaing dengan mahasiswa dari Perguruan Tinggi yang lain.

Prototype sistem informasi bisnis berbasis web ini juga dapat di akses oleh siapapun yang membutuhkan informasi mengenai produk dan jasa yang dihasilnya oleh mahasiswa Kota Semarang, dengan lebih cepat, dibandingkan dengan harus mencari daftar usaha di setiap Perguruan Tingginya masing-masing. Oleh karena itu, peran Perguruan Tinggi dan dinas pendidikan diperlukan dalam mendorong keberhasilan sistem informasi bisnis mahasiswa untuk memperluas akses komunikasi 
melalui pemberian fasilitas teknologi informasi berbasis web yang dapat digunakan sebagai media komunikasi secara global.

Teknologi informasi merupakan bentuk teknologi yang digunakan untuk menciptakan, menyimpan, mengubah dan menggunakan informasi dalam segala bentuknya. Melalui pemanfaatan teknologi informasi ini, mahasiswa di semua Perguruan Tinggi di Kota Semarang dapat mengenalkan produk dan jasa yang dihasilkan kepada masyarakat luas. Perusahaan yang awalnya kecil seperti toko buku Amazon, portal Yahoo dan perusahaan lelang sederhana Ebay, ketiganya saat ini menjadi perusahaan raksasa hanya dalam waktu singkat karena memanfaatkan teknologi informasi dalam mengembangkan usahanya (Hartono 2005).

Pemanfaatan teknologi informasi dalam mengenalkan produk-produk unggulannya bagi perusahaan kecil dapat memberikan fleksibilitas dalam promosi produk dan jasa yang di tawarkan oleh mahasiswa, memungkinkan banyaknya masyarakat yang akan mengetahui produk dan jasa yang dihasilkan secara lebih cepat, mengirimkan dan menerima informasi secara cepat dan hemat, serta mendukung pengembangan sistem informasi itu sendiri. Hal tersebut juga secara tidak langsung mengangkat nama Perguruan Tinggi mereka di mata masyarakat. Kesuksesan program usaha dan bisnis untuk mahasiswa dalam sebuah Perguruan Tinggi, dapat terlihat dengan antusias masyarakat membeli produk dan memesan jasa hasil karya mahasiswa tersebut.

Pemanfaatan internet yang merata di segala bidang memungkinkan mahasiswa mengenalkan produk dan jasa yang dihasilkan lebih luas lagi ke masyarakat. Dengan dibuatnya sebuah prototype sistem informasi berbasis web untuk mengenalkan produk-produk unggulan yang telah dihasilkan oleh mahasiswa di Kota Semarang, diharapkan dapat memudahkan pihak-pihak yang membutuhkan produk dan jasa karya mahasiswa lebih cepat mendapatkan informasi yang mereka butuhkan. Perguruan Tinggi merupakan pihak yang sangat berkompeten dalam menciptakan mahasiswa berjiwa usaha. Prototype sistem informasi bisnis berbasis web secara tidak langsung akan membawa Perguruan Tinggi yang bersangkutan dikenal oleh masyarakat luas. Kinerja Perguruan Tinggi dalam menciptakan pengusaha-pengusaha muda dapat dinilai dari keberhasilan mahasiswanya menjadi pribadi yang mandiri yang dapat menciptakan produk dan jasa yang dibutuhkan oleh masyarakat. Selain Perguruan Tinggi, pihak lain yang sangat penting adalah dinas pendidikan. Melalui Dinas Pendidikan Provinsi Jawa Tengah, prototype sistem informasi bisnis berbasis web untuk mahasiswa Kota Semarang ini dapat diakses. Web yang berisi produk-produk dan jasa yang dihasilkan oleh mahasiswa yang berdomisili di Kota Semarang ini, secara tidak langsung dapat menjadikan Kota Semarang dikenal sebagai kota yang mengenalkan produk-produk dan jasa yang dihasilkan para mahasiswa yang ada di wilayahnya. 


\section{TUJUAN DAN MANFAAT PENELITIAN}

\section{Tujuan Penelitian}

Dalam perkembangannya, program usaha dan bisnis mahasiswa di Kota Semarang sampai saat ini belum disediakan sistem informasi secara khusus. Hasilhasil karya mahasiswa di bidang usaha, hanya dikenalkan di situs yang dimiliki oleh Perguruan Tinggi masing-masing. Dengan dibuatnya prototype sistem informasi bisnis bagi mahasiswa ini, mahasiswa memiliki wadah khusus dalam mengenalkan produk maupun jasa hasil karya mereka. Seluruh mahasiswa di Kota Semarang dapat melihat produk dan jasa yang dihasilkan oleh mahasiswa lain dari Perguruan Tinggi yang lain pula. Bila perkembangannya bagus, tidak menutup kemungkinan bila prototype sistem informasi bisnis dapat diakses di lamannya Dinas Pendidikan Provinsi Jawa Tengah. Dengan demikian Dinas Pendidikan Provinsi Jawa Tengah dapat menjadi fasilisator dalam mengenalkan hasil karya mahasiswa Kota Semarang di bidang usaha.

\section{Manfaat Penelitian}

Mahasiswa di wilayah Kota Semarang perlu mendapatkan tempat untuk mengenalkan produk dan jasa hasil karya mereka. Dengan prototype sistem informasi bisnis, informasi dapat diakses oleh masyarakat luas dengan mudah dan cepat, baik informasi mengenai produk maupun jasa yang dihasilkan. Manfaat dari pembuatan prototype sistem informasi bisnis bagi mahasiswa Kota Semarang adalah: mahasiswa dapat memahami keterkaitan erat antara bisnis dengan penggunaan sistem informasi dan teknologi informasi dalam kegiatan bisnisnya, mahasiswa secara tidak langsung mendapatkan wawasan awal tentang proses analisa strategi bisnis. Mahasiswa dapat mengetahui komponen penting terkait proses analisa strategi bisnis melalui media website, mahasiswa dapat bersaing dengan mahasiswa Perguruan Tinggi lain dalam meningkatkan produk unggulan yang memiliki kualitas berdaya jual tinggi dan Perguruan Tinggi dapat menginformasikan ke masyarakat luas mengenai hasil karya mahasiswanya di masyarakat luas. Perguruan Tinggi akan terus berkompetensi guna menghasilkan calon pengusaha-pengusaha muda yang dapat mengantisipasi pengangguran dan dapat mengangkat nama baik Kota Semarang melalui usahanya.

\section{KAJIAN PUSTAKA}

Menurut hasil penelitian dari Peny et al. (2010), salah satu cara untuk menumbuhkan jiwa berwirausaha di kalangan mahasiswa adalah dengan mengembangkan kewirausahaan yang berbasis teknologi (technopreneurship). Technopreneurship Course Development merupakan program pengembangan kurikulum technopreneurship dari RAMP IPB yang bekerjasama dengan berbagai Perguruan Tinggi, untuk merancang kurikulum dan pengajaran materi inovasi teknologi yang dapat memberikan dampak sosial dan ekonomi, yang menjadikan 
teknologi sebagai solusi bagi permasalahan yang dihadapi oleh masyarakat miskin. Kegiatan ini merupakan wadah untuk meningkatkan kesadaran mahasiswa dalam menciptakan teknologi baru serta pengembangan bisnis berbasis inovasi. Pengembangan kurikulum ini juga diharapkan dapat menunjukkan komitmen dari institusi pendidikan tinggi untuk meningkatkan kualitas perkuliahan melalui experiential learning.

Better information for better business, ungkapan tersebut menunjukkan betapa pentingnya cara pengelolaan informasi untuk sebuah bisnis. Sistem informasi bisnis adalah bidang minat yang mendalami teknik pendayagunaan data untuk mendukung aktivitas bisnis serta pengambilan keputusan yang akurat. Mahasiswa dibekali pengetahuan tentang teknik analisis dan desain sistem informasi serta menggunakan software untuk solusi bisnis, termasuk manajemen data. Saat ini, kebanyakan sistem informasi bisnis dikembangkan dengan basis data dan memakai teknologi internet. Jadi, atas dasar kebutuhan dari dunia bisnis modern inilah, bidang minat bisnis dan usaha ini marak ditawarkan oleh Perguruan Tinggi sebagai materi kuliah unggulan di Fakultas Ekonomi dan Bisnis.

Persaingan bisnis menuntut pengusaha untuk menyusun kembali strategi dan taktik bisnisnya. Jika dilihat lebih mendalam, ternyata esensi dari persaingan terletak pada bagaimana sebuah bisnis dapat mengimplementasikan proses penciptaan produk dan atau jasanya secara lebih murah, lebih baik dan lebih cepat dibandingkan dengan pesaing bisnisnya.

Saat ini penerapan teknologi informasi dan komunikasi diperlukan dalam dunia bisnis sebagai alat bantu dalam upaya memenangkan persaingan. Penerapan teknologi informasi yang dilakukan dikategorikan sebagai: pertama, aplikasi teknologi informasi yang menjadi landasan dari berbagai aplikasi lain yang ada di dalam perusahaan antara lain sistem operasi, basis data, network management dan lain-lain. Kedua, aplikasi yang sifatnya mendasar (utility) yaitu aplikasi teknologi informasi yang dipergunakan untuk berbagai urusan utilisasi sumber daya perusahaan antara lain sistem penggajian, sistem akuntansi dan keuangan dan lainlain. Ketiga, aplikasi teknologi informasi yang sesuai dengan kebutuhan spesifik perusahaan terutama yang berkaitan dengan proses penciptaan produk/jasa yang ditawarkan.

Hambatan yang muncul dalam menerapkan kewirausahaan untuk mahasiswa tidak hanya di bidang teknologi saja tetapi menurut hasil penelitian Peny et al. (2010) adalah metoda pembelajaran yang dilakukan di kelas yang mempengaruhi kemampuan mahasiswa di bidang wirausaha. Hambatan tersebut adalah sebagai berikut: materi yang disampaikan hanya menjadi pengetahuan, tidak menjadi praktik (aplikasi). Studi kasus yang dipelajari di kelas berdasarkan data sekunder (artikel) sehingga analisis tidak aktual dan dialogis. Selain itu, studi kasus terdiri dari banyak tema sehingga pemecahan masalah satu aspek tidak berkelanjutan pada tahap berikutnya. Ketiadaan obyek usaha yang spesifik sehingga informasi tentang bisnis tertentu tidak komprehensif. Informasi yang didapatkan untuk menyusun rencana, proposal dan 
evaluasi bisnis tidak valid dan riil serupa dengan kondisi lapangan. Tidak tersedia laboratorium produksi yang memadai sehingga mahasiswa memiliki gambaran menjalankan bisnis sejak produksi, pemasaran dan keuangan yang harus dikelola.

\section{Pengertian Wiraswasta}

Wiraswasta berasal dari Bahasa Sansekerta, terdiri dari tiga suku kata: "wira", "swa" dan "sta". Wira berarti manusia unggul, teladan, tangguh, berbudi luhur, berjiwa besar, berani, pahlawan, pionir, pendekar/pejuang kemajuan, memiliki keagungan watak. Swa berarti sendiri dan sta berarti berdiri.

Hills (2008), mengungkapkan bahwa "wiraswasta" atau "pengusaha" diambil dari Bahasa Perancis entrepreneur yang pada mulanya berarti pemimpin musik atau pertunjukkan lainnya. Dalam ilmu ekonomi, seorang pengusaha berarti seorang pemimpin ekonomi yang memiliki kemampuan untuk mendapatkan peluang secara berhasil memperkenalkan mata dagangan baru, teknik baru, sumber pemasukan baru, serta pabrik, peralatan, manajemen, tenaga buruh yang diperlukan dan mengorganisasikannya ke dalam suatu teknik pengoperasian perusahaan. Pengertian entrepreneur adalah mereka yang memulai sebuah usaha baru dan yang berani menanggung segala macam risiko serta mereka yang mendapatkan keuntungan.

Dapat disimpulkan bahwa istilah wiraswasta dan wirausaha berasal dari istilah yang sama yaitu entrepreneur. Oleh karena itu, istilah wirausaha dapat diartikan sebagai manusia unggul yang mampu melakukan kegiatan/pekerjaan untuk mencapai suatu maksud yang dalam bidang perdagangan/perusahaan dengan maksud mencari untung, bahkan mampu membantu terutama dalam menciptakan lapangan kerja bagi orang lain.

\section{Pengertian Kewirausahaan}

Dalam mengartikan kewirausahaan terlebih dahulu harus memahami arti dari wirausaha dan wirausahawan. Wirausaha dari segi etimologi berasal dari kata wira dan usaha. Wira berarti pejuang, pahlawan, manusia unggul, teladan, berbudi luhur, gagah berani dan berwatak agung. Usaha berarti perbuatan amal, berbuat sesuatu. Wirausahawan menurut Joseph Schumpeter adalah seorang inovator yang mengimplementasikan perubahan-perubahan di dalam pasar melalui kombinasikombinasi baru. Kombinasi baru tersebut bisa dalam bentuk: memperkenalkan produk baru, memperkenalkan metoda produksi baru, membuka pasar yang baru (new market), memperoleh sumber pasokan baru dari bahan atau komponen baru, atau menjalankan organisasi baru pada suatu industri. Dari arti wirausaha dan wirausahawan tersebut, maka kewirausahaan dapat diartikan sebagai berikut:

a. Kewirausahaan adalah suatu nilai yang diwujudkan dalam perilaku yang dijadikan dasar sumber daya, tenaga penggerak, tujuan, siasat, kiat, proses dan hasil bisnis (Sanusi 1994).

b. Kewirausahaan adalah suatu kemampuan untuk menciptakan sesuatu yang baru dan berbeda (ability to create the new and different) (Drucker 1959). 
c. Kewirausahaan adalah suatu proses penerapan kreativitas dan inovasi dalam memecahkan persoalan dan menemukan peluang untuk memperbaiki kehidupan (Zimmerer 1996).

d. Kewirausahaan adalah suatu nilai yang diperlukan untuk memulai suatu usaha (star-up phase) dan perkembangan usaha (venture growth) (Prawiro 1997).

e. Kewirausahaan adalah semangat, sikap, perilaku dan kemampuan seseorang dalam menangani usaha atau kegiatan yang mengarah pada upaya mencari, menciptakan, serta menerapkan cara kerja, teknologi dan produk baru dengan meningkatkan efisiensi dalam rangka memberikan pelayanan yang lebih baik dan atau memperoleh keuntungan yang lebih besar (Keputusan Menteri Koperasi dan Pembinaan Pengusaha Kecil Nomor 961/KEP/M/XI/1995).

f. Kewirausahaan adalah suatu kemampuan (ability) dalam berfikir kreatif dan berperilaku inovatif yang dijadikan dasar, sumber daya, tenaga penggerak tujuan, siasat kiat dan proses dalam menghadapi tantangan hidup (Spemahamidjaja 1977).

g. Kewirausahaan adalah suatu sifat keberanian, keutamaan dalam keteladanan dalam mengambil risiko yang bersumber pada kemampuan sendiri (Wijandi 1988).

h. Kewirausahaan didefinisikan sebagai bekerja sendiri (self-employment) (Cantillon 1973).

Dari berbagai pendapat para ahli di atas, maka dapat disarikan bahwa pengertian kewirausahaan adalah sebuah proses mengkreasikan dengan menambahkan nilai sesuatu yang dicapai melalui usaha keras dan waktu yang tepat dengan memperkirakan dana pendukung, fisik, risiko sosial dan akan menerima reward berupa keuangan dan kepuasan serta kemandirian personal.

Melalui pengertian tersebut, terdapat empat ciri yang dimiliki oleh seorang wirausahawan, yaitu pertama, proses berkreasi yakni mengkreasikan sesuatu yang baru dengan menambahkan nilainya. Penambahan nilai ini tidak hanya diakui oleh wirausahawan semata, tetapi juga oleh konsumen yang akan menggunakan hasil kreasi tersebut. Kedua, komitmen yang tinggi terhadap penggunaan waktu dan usaha yang diberikan. Semakin besar fokus dan perhatian yang diberikan dalam usaha ini maka akan mendukung proses kreasi yang akan timbul dalam kewirausahaan. Ketiga, memperkirakan risiko yang mungkin timbul. Dalam kondisi ini risiko yang mungkin terjadi berkisar pada risiko keuangan, fisik dan risiko sosial dan memperoleh reward. Dalam hal ini reward yang terpenting adalah independensi atau kebebasan yang diikuti dengan kepuasan pribadi, sedangkan reward berupa uang biasanya dianggap sebagai suatu bentuk derajat kesuksesan usahanya.

\section{Pengertian Teknologi Informasi dan Komunikasi (TIK)}

Pada era globalisasi sekarang ini, perkembangan teknologi informasi sangatlah pesat dimana membawa pengaruh yang cukup besar dalam berbagai 
bidang, khususnya dalam bidang usaha. Seorang pengusaha memerlukan bantuan suatu sistem informasi yang terkomputerisasi dengan baik untuk memaksimalkan kinerja bisnis dalam mengatur sebuah bisnis. Selain itu, sistem informasi yang telah terintegrasi ini juga dapat memberikan informasi yang cepat, akurat, relevan, lengkap dan tepat kepada pengusaha dalam menentukan langkah langkah bisnis selanjutnya.

Ada beberapa pengertian TIK oleh beberapa ahli. Menurut Deeson (1991)

\begin{abstract}
"Information Technology (IT) the handling of information by electric and electronic (and microelectronic) means. "Here handling includes transfer. Processing, storage and access, IT special concern being the use of hardware and software for these tasks for the benefit of individual people and society as a whole."
\end{abstract}

Dari penjelasan di atas dapat diartikan bahwa teknologi informasi adalah kebutuhan manusia di dalam mengambil dan memindahkan, mengolah dan memproses informasi dalam konteks sosial yang menguntungkan diri sendiri dan masyarakat secara keseluruhan. Menurut Puskur Diknas Indonesia, Teknologi Informasi dan Komunikasi (TIK) mencakup dua aspek, yaitu Teknologi Informasi dan Teknologi Komunikasi. Teknologi Informasi adalah meliputi segala hal yang berkaitan dengan proses, penggunaan sebagai alat bantu, manipulasi dan pengelolaan informasi. Teknologi Komunikasi adalah segala hal yang berkaitan dengan penggunaan alat bantu untuk memproses dan mentransfer data dari perangkat yang satu ke lainnya.

Menurut Hartono (2005), informasi merupakan hasil dari pengolahan data namun tidak semua hasil dari pengolahan tersebut dapat menjadi informasi. Dari penjelasan diatas dapat disimpulkan bahwa teknologi informasi dan teknologi komunikasi adalah suatu padanan yang tidak terpisahkan yang mengandung pengertian luas tentang segala kegiatan yang terkait dengan pemrosesan, manipulasi, pengelolaan dan transfer/pemindahan informasi antar media.

Jadi pengertian TIK adalah sebuah media atau alat bantu yang dapat digunakan untuk mentransfer data, baik menerima informasi maupun dalam memberikan informasi kepada orang lain yang dalam praktiknya sangat berperan dalam kelancaran komunikasi, satu maupun dua arah. Beranjak dari pengertian TIK tersebut tentu saja sebuah Perguruan Tinggi memerlukan alat ini dalam hal pencarian informasi seputar perkembangan produk yang sedang dikerjakan serta memberikan informasi kepada khalayak ramai terkait produk dan jasa yang dihasilkan para mahasiswanya yang akhirnya pengenalan produk tersebut akan berjalan lancar. Bukan hanya itu, ketika sebuah Perguruan Tinggi berbasis TIK maka kinerja dan pelaksanaannya akan semakin mudah melalui komunikasi dengan pelanggan melalui media tanpa harus memakan waktu lama untuk bertemu langsung.

Salah satu kendala utama yang sering dihadapi oleh setiap Perguruan Tinggi adalah pengenalan produk dan jasa hasil karya mahasiswa hanya di kenalkan melalui situs Perguruan Tinggi. Belum ada situs khusus yang hanya memuat mengenai aktifitas mahasiswa di bidang bisnis. Mahasiswa membutuhkan sistem informasi 
yang terkomputerisasi untuk menunjang usahanya. Saat ini internet sudah merupakan hal biasa di setiap lapisan masyarakat, sehingga aplikasi ini dapat diimplementasikan ke dalam bentuk web.

Melalui TIK berbasis web, Perguruan Tinggi dapat mengenalkan hasil karya mahasiswa di bidang bisnis kepada masyarakat secara luas dan data mengenai produk dan jasa karya mahasiswa yang dibutuhkan, dapat dengan mudah diketahui oleh masyarakat luas. Oleh karena itu, peran Dinas Pendidikan Provinsi Jawa Tengah diperlukan dalam mendorong keberhasilan para mahasiswa Kota Semarang untuk memperluas informasi melalui pemberian fasilitas teknologi informasi berbasis web yang dapat digunakan sebagai media komunikasi secara global. Oleh karena itu, agar mahasiswa dengan segala keterbatasannya dapat berkembang dengan memanfaatkan teknologi informasi, perlu dukungan berupa pelatihan dan penyediaan fasilitas. Tentu saja tanggung jawab terbesar untuk memberi pelatihan dan penyediaan fasilitas ini ada di tangan Perguruan Tinggi, di samping pihak-pihak lain yang punya komitmen, khususnya kalangan Perguruan Tinggi.

\section{Pengertian Sistem Informasi}

Sistem informasi adalah suatu sistem di dalam suatu organisasi yang mempertemukan kebutuhan transaksi harian yang mendukung fungsi operasi organisasi yang bersifat manajerial dan kegiatan strategi dari suatu organisasi untuk dapat menyediakan kepada pihak luar tertentu dengan laporan-laporan yang diperlukan (Hartono 2005). Dengan telah dikembangkannya sistem yang baru, maka diharapkan akan terjadi peningkatan-peningkatan sistem yang baru. Dalam pengembangan sistem diperlukan tahapan proses analisis kemudian dilanjutkan dengan tahapan desain sistem, karena kedua hal tersebut merupakan hal yang utama dalam pengembangan sistem itu sendiri.

Beberapa tahapan dalam proses pengembangan sistem yang perlu diperhatikan diantaranya adalah analisis sistem dan desain sistem. Analisis sistem adalah penguraian dari suatu sistem informasi yang utuh ke dalam bagian-bagian komponen-komponennya dengan maksud untuk mengidentifikasikan dan mengevaluasi permasalahan-permasalahan, kesempatan-kesempatan, hambatanhambatan yang terjadi dan kebutuhan-kebutuhan yang diharapkan sehingga dapat diusulkan perbaikan-perbaikannya.

Tahap analisis sistem dilakukan setelah tahap perencanaan sistem dan sebelum tahap desain sistem. Tahap analisis merupakan tahap yang kritis dan sangat penting, karena kesalahan di tahap ini akan menyebabkan juga di tahap selanjutnya (Hartono 2005). Desain sistem dapat didefinisikan sebagai penggambaran, perencanaan dan pembuatan sketsa atau pengaturan dari beberapa elemen yang terpisah ke dalam satu kesatuan yang utuh dan berfungsi (Hartono 2005).

Beranjak dari pengertian Sistem Informasi tersebut tentu saja sebuah Usaha Mikro, Kecil dan Menengah (UMKM) memerlukan alat ini dalam hal pencarian 
informasi seputar perkembangan produk yang sedang dikerjakan serta memberikan informasi kepada khalayak ramai terkait produk UMKM yang akhirnya pemasaran akan berjalan lancar. Bukan hanya itu, ketika sebuah UMKM berbasis web maka kinerja dan pelaksanaannya akan semakin mudah melalui komunikasi dengan pelanggan melalui media tanpa harus memakan waktu lama untuk bertemu langsung.

Oleh karena itu, agar UMKM dengan segala keterbatasannya dapat berkembang dengan memanfaatkan teknologi informasi, perlu dukungan berupa pelatihan dan penyediaan fasilitas. Tentu saja tanggung jawab terbesar untuk memberi pelatihan dan penyediaan fasilitas ini ada di tangan pemerintah, disamping pihak-pihak lain yang punya komitmen, khususnya kalangan Perguruan Tinggi.

\section{Sistem Flowchart}

Sistem flowchart adalah perangkat diagram grafik yang menyimpan dan mengkomunikasikan aliran data media dan prosedur proses informasi yang diperlukan dalam sistem informasi. Hal ini dilakukan dengan menggunakan berbagai simbol yang dihubungkan dengan panah-panah untuk menunjukkan kelanjutan aktivitas proses informasi. Sistem flowchart tertentu berfungsi penting sebagai media dan hardware yang digunakan dan proses yang berhubungan dengan sistem informasi. Semua itu mewakili model grafis dari sistem informasi fisik yang diperlukan atau diajukan.

Sistem ini banyak dipakai untuk menghubungkan struktur menyeluruh dan aliran sistem ke pengguna akhir karena sistem ini dapat menawarkan tampilan fisik yang berperan penting pada keterkaitan hardware dan data media. Walaupun begitu, beberapa kasus, sistem tersebut dapat digantikan dengan diagram aliran data untuk digunakan oleh analis sistem profesional dan dengan grafik presentasi untuk berkomunikasi dengan pengguna akhir.

\section{Situs Web}

Situs web adalah sejumlah halaman web yang memiliki topik saling terkait, terkadang disertai pula dengan berkas-berkas gambar, atau jenis-jenis berkas lainnya. Sebuah situs web biasanya ditempatkan setidaknya pada sebuah server web yang dapat diakses melalui jaringan seperti internet, ataupun jaringan wilayah lokal Local Area Network (LAN) melalui alamat internet yang dikenali sebagai Uniform Resource Locator (URL). Gabungan atas semua situs yang dapat diakses publik di internet disebut pula sebagai World Wide Web atau lebih dikenal dengan singkatan $w w w$. Meskipun setidaknya halaman beranda situs internet umumnya dapat diakses publik secara bebas, pada praktiknya tidak semua situs memberikan kebebasan bagi publik untuk mengaksesnya, beberapa situs web mewajibkan pengunjung untuk melakukan pendaftaran sebagai anggota, atau bahkan meminta pembayaran untuk dapat menjadi anggota untuk dapat mengakses isi yang terdapat dalam situs web tersebut, misalnya situs-situs yang menampilkan pornografi, situs-situs berita, 
layanan surel (e-mail) dan lain-lain. Pembatasan-pembatasan ini umumnya dilakukan karena alasan keamanan, menghormati privasi, atau karena tujuan komersil tertentu.

\section{Prototype}

Sebuah prototype adalah tipe yang asli, bentuk, atau contoh dari sesuatu yang dipakai sebagai contoh yang khas, dasar, atau standar untuk hal-hal lain dari kategori yang sama. Dalam bidang desain, sebuah prototype dibuat sebelum dikembangkan atau justru dibuat khusus untuk pengembangan sebelum dibuat dalam skala sebenarnya atau sebelum diproduksi secara massal. Kategori prototype dasar, tidak ada kesepakatan umum tentang apa yang merupakan prototype dan kata tersebut sering digunakan bergantian dengan kata "model".

\section{METODA PENELITIAN}

Metoda penelitian yang digunakan dalam rancang bangun prototype praktik wirausaha mahasiswa adalah dengan sistem flowchart. Sistem flowchart dapat memberikan gambaran yang jelas mengenai alur prototype yang akan dibuat untuk mengenalkan hasil karya mahasiswa di bidang wirausaha. Sedangkan pengambilan data dilakukan dengan metoda wawancara dan observasi. Wawancara diawal dilakukan ke kepala program studi Ekonomi dan Bisnis mengenai manfaat teknologi dalam mendukung pengenalan hasil usaha para mahasiswanya dan dari penelitian pendahuluan, di ambil lima sampel PTS besar di Kota Semarang yang ternyata belum memanfaatkan teknologi guna memasarkan hasil usaha para peserta didiknya. Laman yang dimiliki hanya dimanfaatkan untuk mengenalkan program wirausaha yang ditawarkan ke masyarakat luas saja. Beberapa diantaranya, laman hanya dimanfaatkan untuk mempublikasikan program wirausaha mahasiswa yang sukses saja dan dapat berjalan hingga menjadi profesi peserta didiknya.

Observasi dilakukan dengan mengamati langsung laman-laman yang dimiliki PTS dan PTN di Kota Semarang dalam mempublikasikan aktifitas mahasiswanya di bidang usaha. Observasi lapangan dilakukan pada PTS memiliki teknologi yang terdepan dalam mempublikasikan lembaganya.

Langkah selanjutnya, sebelum merancang sistem flowchat, maka dibuatlah bagan alir pembuatan prototype terlebih dahulu. Bagan alir dibuat, agar proses pembuatan rancang bangun prototype dapat dilaksanakan sesuai dengan tujuan pembuatan rancang bangun prototype. Bagan alir dibuat dengan tahapan-tahapan yang tertera pada Gambar 1.

Sedangkan proses pembuatan rancang bangun prototype melalui langkahlangkah sebagai berikut. Pertama adalah studi pendahuluan, yaitu untuk menghasilkan data yang akurat sesuai dengan apa yang dibutuhkan. Hal-hal yang dilakukan adalah: mengumpulkan data berupa jurnal-jurnal ilmiah dan buku-buku pendukung mengenai rancang bangun prototype untuk kegiatan usaha mahasiswa, 
mendata PTN/PTS di Kota Semarang yang dalam penyelenggaraan pendidikannya mengadakan studi usaha dan bisnis untuk para mahasiswanya dan mengamati kecenderungan masyarakat luas yang mulai mengandalkan media online untuk mencari barang dan jasa yang diinginkan.

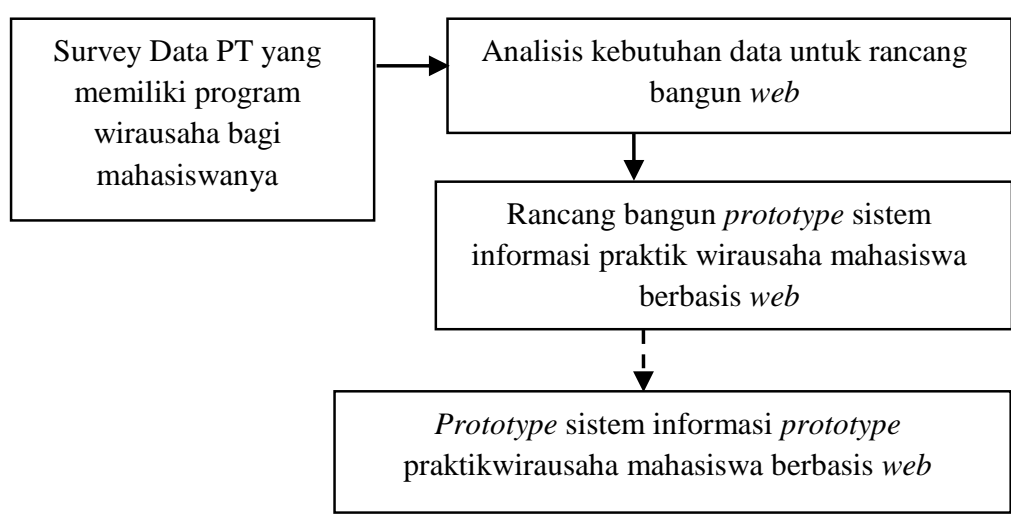

\section{Gambar 1 \\ Bagan Alir Rancang Bangun Prototype}

Kedua adalah survey (Observasi dan Wawancara). Setelah melakukan studi pendahuluan, maka hal selanjutnya yang dilakukan adalah melakukan survey. Survey diawali dengan mendata kegiatan mahasiswa di bidang usaha dan melakukan survey PTN/PTS di Kota Semarang. Beberapa PTN/PTS telah melakukan upload hasil karya mahasiswanya di bidang usaha melalui website yang dimiliki oleh Perguruan Tingginya. Website yang ada akan dikaji nantinya untuk dijadikan website Sistem Informasi Bisnis mahasiswa yang ada di Semarang. Survey dilakukan dengan metoda observasi dan wawancara, baik dengan mahasiswa sebagai pelaku usaha maupun PTN/PTS sebagai penyelenggara pendidikan.

Ketiga, analisis kebutuhan sistem. Yang dilakukan dalam menganalisa kebutuhan sistem adalah mendata kebutuhan apa saja untuk mendukung pembuatan prototype sistem informasi praktik wirausaha mahasiswa yang ada di Kota Semarang. Kebutuhan sistem meliputi: perangkat keras, perangkat lunak, sumber daya manusia, serta jaringan internet.

Keempat adalah desain sistem. Tahap desain sistem merupakan tahap merancang bangun sistem informasi praktik wirausaha mahasiswa. Rancang sistem yang digunakan adalah system flowchat. Berikutnya adalah pengujian prototype, dimana pengujian prototype dilakukan setelah desain sistem selesai dibuat, maka pembuatan prototype dilaksanakan. Diharapkan prototype yang dibuat dapat diuji apakah prototype yang dibuat sudah sesuai dengan yang tujuan yang akan dicapai.

Tahap selanjutnya adalah implementasi, yaitu proses penerapan rancang bangun yang telah dibuat. Diharapkan, setelah diimplementasikan banyak sekali masukan dari para pengguna sistem untuk kemajuan sistem informasi praktik 
wirausaha mahasiswa tersebut. Kemudian sosialisasi dan evaluasi, dimana setelah adanya perbaikan dari proses penerapan rancang bangun prototype, maka prototype siap disosialisasikan ke PTN/PTS serta mahasiswa yang mengambil studi usaha dan bisnis untuk dapat di evaluasi agar prototype nantinya dapat menjadi sistem master yang bermanfaat bagi PTN/PTS, mahasiswa, serta masyarakat luas.

Langkat selanjutnya validasi dan pengelolaan sistem. Apabila rancang bangun prototype sistem informasi bagi mahasiswa layak di terapkan, maka akan dibuat sistem informasi praktik wirausaha mahasiswa yang nantinya proses pengelolaan lebih lanjut di serahkan ke Dinas pendidikan Provinsi Jawa Tengah. Prototype dapat dilink oleh PTN/PTS dengan menggunakan hak akses sebagai PTN/PTS yang menaungi para mahasiswanya. Tahap terakhir adalah dokumentasi. Proses dokumentasi dilakukan sejak awal pelaksanaan kegiatan sampai akhir kegiatan penelitian. Dokumentasi menceritakan proses berjalannya penelitian, dari mulai studi pendahuluan sampai validasi dan pengelolaan sistem. Dokumentasi sangat penting sebagai acuan pengembangan sistem di kemudian hari.

\section{PEMBAHASAN}

Rancangan bangun prototype merupakan teknologi yang akan digunakan dalam kegiatan ini lebih bersifat teknologi tepat guna yang disesuaikan dengan produk inovasi yang direncanakan. Pada pengenalan usaha yang dilakukan oleh mahasiswa akan digunakan teknologi informasi yang sesuai dan mudah untuk diakses oleh siapa saja. Pembuatan rancang bangun prototype sebagai implementasi praktik wirausaha mahasiswa menjadi cakupan utama selain metoda desain yang telah umum dilakukan.

Produk maupun jasa yang dihasilkan oleh mahasiswa merupakan sesuatu hal yang penting dari proses inovasi dalam tahap komersialisasi. Tahap komersialisasi membuat produk yang telah dihasilkan melalui proses kreativitas dan inovasi tersebut dapat diterima oleh pasar.

Strategi komersialisasi yang dilakukan akan sangat tergantung pada jenis produk yang dihasilkan. Secara umum strategi yang dilakukan adalah dengan mengoptimalkan media promosi dengan Word of Mouth (WOM) selain media yang lain seperti advertising, promosi langsung, mengikuti pameran dan model konsinyasi. Potensi pasar terbesar untuk usaha-usaha tersebut adalah mahasiswa dan masyarakat umum yang berada di sekitar lokasi usaha. Pada akhirnya diharapkan bahwa produk yang dihasilkan akan memiliki nilai tambah bagi kelompok maupun jurusan pada umumnya.

Rancang bangun prototype sistem informasi praktik wirausaha mahasiswa diawali dengan sistem flowchat menu utama, dimana dalam alur sistem menu utama tersebut, digambarkan proses pengguna (user) dapat mengakses ke sistem prototype. Adapun perancangan sistem yang ditawarkan ada pada Gambar 2. 
Data yang dipergunakan dilakukan uji normalitas dengan uji One-Sample Kolmogorof-Smirnov dan hasilnya adalah normal lebih besar dari 0,05. Selanjutnya distribusi data dengan pola kurva normal dapat dilihat pada Gambar 4 histogram dengan kurva normal pada distribusi data setiap variabel.

Setelah pengguna (user) masuk ke dalam prototype sistem informasi praktik wirausaha mahasiswa di Kota Semarang, maka user dapat memilih berbagai menu yang ditawarkan oleh sistem adalah: beranda, merupakan menu awal tampilan dari sistem prototype. Dalam beranda terdapat informasi terbaru mengenai peristiwa ataupun kegiatan-kegiatan yang berhubungan dengan informasi mengenai kegiatan kewirausahaan yang sedang dilakukan oleh mahasiswa dari suatu Perguruan Tinggi. Informasi terbaru mengenai kegiatan-kegiatan mahasiswa yang ada di Kota Semarang dalam berwirausaha juga dapat dilihat dalam menu beranda tersebut.

Produk wirausaha, merupakan menu dimana hasil karya mahasiswa dalam menjalankan program wirausaha dapat dilihat oleh pengunjung web. Dalam menu produk wirausaha, ditampilkan informasi mengenai produk atau jasa hasil praktik wirausaha mahasiswa, baik warna, ukuran, harga maupun jenis produk, serta Perguruan Tinggi dimana mahasiswa tersebut menuntut ilmu.

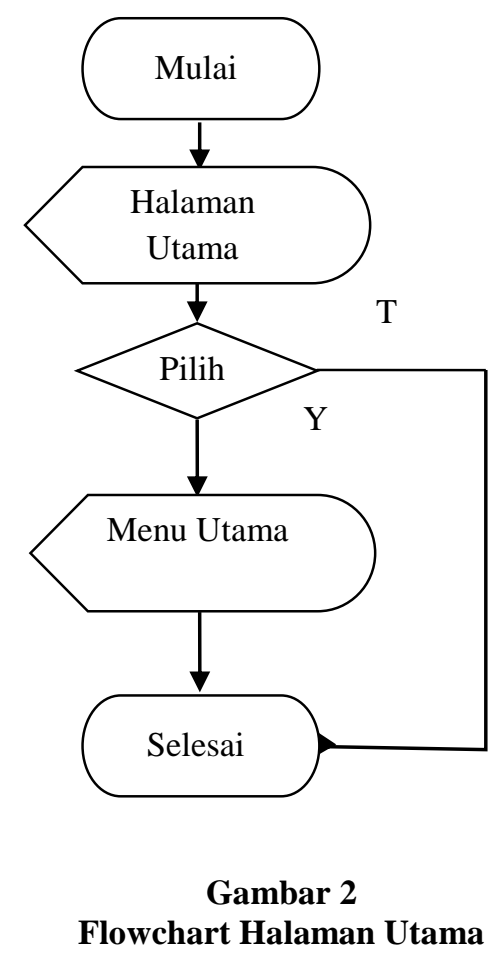

Kemudian, peta lokasi, merupakan menu yang menampilkan lokasi tempat Perguruan Tinggi para mahasiswa menjalani program wirausaha. Perguruan Tinggi, merupakan menu yang menampilkan daftar Perguruan Tinggi yang menyelenggarakan program wirausaha untuk para mahasiswanya. Menu Perguruan Tinggi juga menampilkan program studi dari mahasiswa yang telah menampilkan 
hasil praktik wirausahanya dalam web. Tentang kami, merupakan menu yang memberikan informasi seluas-luasnya kepada user mengenai pengelola web dan pembuatan sistem prototype praktik wirausaha mahasiswa di Kota Semarang dan di bagian terakhir ada hubungi kami, merupakan menu yang berisi informasi mengenai alamat dan nomer penting yang dapat dihubungi oleh user apabila user menginginkan konsultasi maupun komunikasi secara langsung dengan pengelola webprototype sistem informasi praktik wirausaha mahasiswa di Kota Semarang.

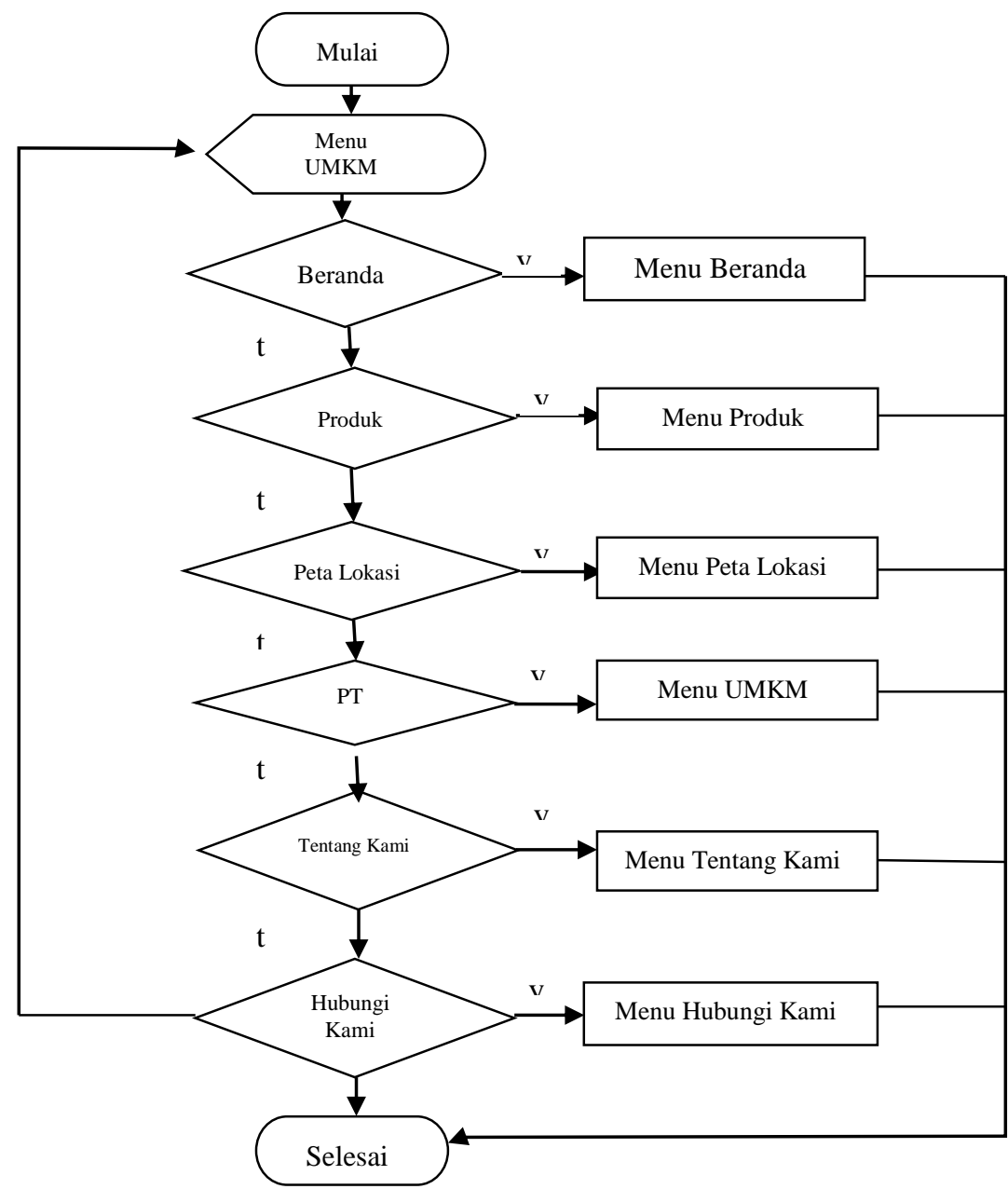

Gambar 3

Flowchart Menu Utama Praktik Wirausaha Mahasiswa

\section{SIMPULAN}

Salah satu penyebab rendahnya aktivitas kewirausahaan di kalangan mahasiswa adalah mahasiswa masih berpikir bahwa kemampuan dan keilmuan yang tinggi, sangat penting bagi mereka untuk memenangkan diri dalam berkompetisi memenuhi lowongan kerja. Masih banyak mahasiswa yang berperan sebagai pencari kerja dari pada sebagai pencipta lapangan kerja. Hal ini mungkin disebabkan oleh karena sistem pembelajaran yang diterapkan di berbagai Perguruan Tinggi lebih terfokus pada bagaimana menyiapkan para mahasiswa yang cepat lulus dan 
mendapat pekerjaan dari pada menciptakan lulusan yang siap menciptakan lapangan kerja. Rendahnya aktivitas kewirausahaan di kalangan mahasiswa ini dapat menyebabkan tingginya angka pengangguran karena tidak ada ekspansi kegiatan usaha.

Salah satu cara untuk menumbuhkan jiwa berwirausaha di kalangan mahasiswa adalah dengan mengembangkan kewirausahaan yang berbasis teknologi (technopreneurship). Technopreneurship memberikan pengajaran mengenai inovasi teknologi yang dapat memberikan dampak sosial dan ekonomi, yang menjadikan teknologi wadah untuk meningkatkan kesadaran mahasiswa dalam menciptakan teknologi baru serta pengembangan bisnis berbasis inovasi.

Kegiatan ini telah membuka wawasan bagi mahasiswa yang berasal dari ilmu ekonomi dan bisnis bahwa pemanfaatan teknologi sebagai dasar berwirausaha dapat dilakukan siapa saja. Komersialisasi hasil-hasil teknologi menjadi penting agar dapat memberi nilai tambah dan manfaat dalam peningkatan kehidupan sosial dan ekonomi masyarakat. Perlu adanya kerjasama yang saling menguntungkan dari pihak Perguruan Tinggi dan dunia usaha agar hasil-hasil praktik wirausaha dapat diaplikasikan dan dimanfaatkan oleh kalangan industri, tidak hanya digunakan sebagai praktik wirausaha di lingkungan Perguruan Tinggi saja.

Dengan dibuatnya rancang bangun prototype sistem informasi praktik wirausaha mahasiswa di Kota Semarang berbasis web, maka didapatkan sebuah gambaran yang jelas mengenai sebuah rancang bangun yang menggambarkan aktifitas mahasiswa di Kota Semarang dalam mengimplementasikan praktik wirausaha yang sedang dijalani secara jelas. Setelah rancang bangun prototype sistem informasi praktik wirausaha mahasiswa di Kota Semarang berbasis web selesai dibuat, diharapkan rancang bangun prototype dapat membuat sistem informasi berbasis web yang komunikatif, menarik dan user friendly. Kemudian yang menjadi tujuan utama adalah dihasilkannya rancang bangun prototype sistem informasi praktik wirausaha mahasiswa berbasis web, sebagai implementasi program wirausaha yang diselenggarakan oleh Perguruan Tinggi yang ada di Kota Semarang.

\section{SARAN}

Pertama, prototype sistem informasi praktik wirausaha mahasiswa di Kota Semarang diharapkan dapat menjadi dasar pembuatan sistem informasi website yang sangat bermanfaat, baik untuk mahasiswa, Perguruan Tinggi, maupun pelaku industri di Kota Semarang. Kedua, prototype yang dibuat rancang bangunnya ini diharapkan dapat dikembangkan lagi agar web yang akan dibuat nantinya menjadi lebih menarik, lengkap dan bermanfaat bagi pengguna sistem dan menjadi tolak ukur keberhasilan penerapan prakek wirausaha mahasiswa di Kota Semarang. Ketiga, rancang bangun prototype perlu dilakukan evaluasi sehingga dapat dilihat apakah perlu diadakannya perbaikan atau penyempurnaan kembali bagi penyempurnaan pembuatan prototype. 


\section{DAFTAR PUSTAKA}

Warsitaningsih, A. S. 2003. Pembelajaran bidang boga sebagai upaya perintisan home industri bagi mahasiswa program studi spesialisasi pendidikan tata boga jurusan PKK FPTK-UPI. Jurusan Pendidikan Kesejahteraan Keluarga FPTK Universitas Pendidikan Indonesia.

Frinces, H. 2004. Kewirausaahaan dan Inovasi Bisnis. Cetakan Pertama. Yogyakarta: Penerbit Darusaalam.

Hills, G. 2008. Marketing and entrepreneur-ship, research ideas and opportunities. Journal of Small and Medium Entrepreneurship.

Hartono, J. 2005. Analisa dan Desain Sistem Informasi. Yogyakarta: Penerbit Andi Yogyakarta.

Keh, H., T. T. M. Nguyen, dan H. P. Eg. 2007. The effects of entrepreneurial orientation and marketing information the performance of SMEs. Journal of Business Venturing.

Laudon, K., dan J. P. Laudon. 2007. Management Information System: Managing the Digital Firm. 10th edition. New Jersey: Prentice Hall.

Oxford University Press. Oxford Advanced Learner's Dictionary. Available at http://www.oxfordadvancedlearnersdictionary.com.

Penny R., H. S. Dyna, dan M. Lies. 2010. Pengembangan kewirausahaan melalui technopreneurship mahasiswa: Kolaborasi kompetensi dan aplikasi teknologi. Jurusan Manajemen Fakultas Ilmu Sosial dan Ekonomi UNY.

Sharing Vision. 2011. Kemandirian Teknologi Masyarakat. Available at http://www.sharingvision.biz.

Shneiderman B., dan C. Plaisant. 2004. Designing the User Interface. 4th edition. New York: Addison Wesley.

Suharto, P. 2010. Kewirausahaan dan Manajemen Usaha Kecil. Edisi 1. Yogyakarta: BPFE.

Turban, E., R. K. Rainer, dan R. E. Potter. 2005. Introduction to Information Technology. 3nd edition. New Jersey: John Wiley \& Sons, Inc.

Layanan Informasi Kopertis VI-PTS-Perguruan Tinggi Swasta di Jawa Tengah. Available at stiead.ptkpt.net-8059. 